\title{
Comparison between cattle manure, organic compost, and vermicompost in the production of Eucalyptus urograndis seedlings
}

\author{
Daniel Pazzini Eckhardt ${ }^{1}$ (iD) Natielo Almeida Santana ${ }^{2}$ (iD Eduardo Lorensi de Souza $^{3}$ (D) \\ Paulo Ademar Avelar Ferreira ${ }^{1}$ (i) Zaida Inês Antoniolli ${ }^{1}$ (i) \\ Jorge Domínguez Martin ${ }^{4}$ (i) Rodrigo Josemar Seminoti Jacques ${ }^{1^{*}}$ (i)
}

\author{
${ }^{1}$ Departamento de Solos, Universidade Federal de Santa Maria (UFSM), 97105900, Santa Maria, RS, Brasil. E-mail: rodrigo@ufsm.br. \\ ${ }^{*}$ Corresponding author. \\ ${ }^{2}$ Departamento de Engenharia Sanitária e Ambiental, Universidade Federal de Santa Maria (UFSM), Santa Maria, RS, Brasil \\ ${ }^{3}$ Universidade Estadual do Rio Grande do Sul (UERGS), Três Passos, RS, Brasil. \\ ${ }^{4}$ Grupo de Ecoloxía Animal, Universidade de Vigo (UVIGO), Vigo, Espanha.
}

\begin{abstract}
Composting and vermicomposting before addition to the soil is a viable alternative to the disposal of cattle manure. However this residue has been used in the untreated form for seedling production. This study evaluated the use of cattle manure in natura, and the organic composted or vermicomposted variants of cattle manure on substrates used in the production of Eucalyptus urograndis seedlings. The treatments consisted of substrates formulated by mixing the organic fertilizers with washed sand in 20, 40, 60, 80 or 100 (v/v) percentages, compared to a commercial substrate. The E. urograndis seedlings were grown in tubes in a greenhouse and evaluated after 120 days for shoot and root dry weights, plant height, stem diameter, shoot/root ratio, and Dickson quality index. The substrate formulated from a mixture of $80 \%$ $(v / v)$ of cattle manure in natura and washed sand allows for better development in Eucalyptus seedlings. Substrate containing 100\% bovine manure vermicompost or organic compost produced seedlings with lower quality than in natura bovine manure but superior to the commercial substrate. Due to the health risks associated with use of untreated bovine manure, organic compost and vermicompost are good alternatives for the production of E. urograndis seedlings.
\end{abstract}

Key words: organic waste, organic fertilizers, substrate, eucalyptus, seedling quality.

Comparação entre esterco bovino, composto orgânico e vermicomposto na produção de mudas de Eucalyptus urograndis

RESUMO: Uma alternativa para destinar corretamente o esterco bovino é realizar a compostagem elou vermicompostagem e depois adicionálo ao solo como fonte de nutrientes às plantas. Porém, este resíduo tem sido utilizado na produção de mudas sem tratamento. O estudo teve por objetivo avaliar o uso de esterco bovino in natura, de composto orgânico e de vermicomposto, produzidos a partir do esterco bovino, em substratos para a produção de mudas de Eucalyptus urograndis. Os tratamentos constituíram-se dos substratos formulados pela mistura dos fertilizantes orgânicos com areia lavada nas porcentagens de 20, 40, 60, 80 e 100 (v/v), em comparação com um substrato comercial (SC). As mudas de Eucalyptus urograndis foram cultivadas em tubetes, em casa de vegetação, e avaliadas aos 120 dias quanto a massa seca da parte aérea e raiz, altura da planta, diâmetro do caule, relação parte aérea/raiz e índice de qualidade de Dickson. O substrato formulado pela mistura de $80 \%(v / v)$ de esterco bovino in natura com areia lavada proporcionou o melhor desenvolvimento das mudas de eucalipto. O substrato contendo $100 \%$ de vermicomposto de esterco bovino ou composto orgânico produziu mudas com qualidade inferior ao esterco bovino in natura, mas superior ao substrato comercial. Devido aos riscos à saúde associados ao uso de esterco bovino não tratado, o composto orgânico e o vermicomposto são boas alternativas para a produção de mudas de E. urograndis.

Palavras-chave: resíduos orgânicos, fertilizantes orgânicos, substrato, eucalipto, qualidade da muda.

\section{INTRODUCTION}

One of the major factors influencing forestry productivity is seedling quality, which requires suitable substrates (LIMA FILHO et al., 2019). A suitable substrate must provide plants with a balanced supply of water, nutrients, and oxygen; present chemical, physical and biological conditions that allow the plant to be sustained; have an appropriate pH; be pathogen, and weed free (SILVA et al., 2017a).
Another important aspect when selecting a substrate is the cost of acquisition (FERMINO et al., 2018); the large amounts used in the nursery are responsible for the main expenditure in seedling production (ABREU et al., 2019). Thus, researching alternative substrates to produce forest seedlings constitutes both economic and environmental necessity, as commercial substrates usually employ mineral fertilizers and other materials from non-renewable sources. Moreover, the use of alternative substrates 
can contribute to the environmentally correct disposal of potential pollutants such as cattle manure, a nutrient-rich waste, and produced in large quantities throughout Brazil (ECKHARDT et al., 2018).

Recommendations for the use of bovine manure as a fertilizer include an a priori treatment by composting and/or vermicomposting (DOMÍNGUEZ \& EDWARDS, 2011). These processes increase mineralization and the availability of nutrients to plants, humidify organic matter, reduce coliform bacteria, worms and weed seed contamination, and improve the remaining physical, chemical, and biological properties of fertilizers (MANÁKOVÁ et al., 2014). However, carrying out composting or vermicomposting requires labour, technical knowledge, adequate facilities, and time (ECHKARDT et al., 2016). For this reason, cattle manure in natura is used as a fertilizer without prior treatment, also in the production of forest seedlings (LISBOA et al., 2018). This study evaluated the use of cattle manure in natura, and the organic composted or vermicomposted variants of cattle manure on substrates used in the production of Eucalyptus urograndis seedlings.

\section{MATERIALS AND METHODS}

\section{Organic fertilizers}

Organic fertilizers were produced from the feedlot cattle manure. The treatment named cattle manure consisted only of air-dried, hand-crushed manure. The organic compost was obtained by mixing cattle manure with hay, consisting mainly of Axonopus affinis, Paspalum notatum, Andropogon lateralis and Aristida laevis species. This composted mixture was injected with air at the bottom of the windrow whenever the temperature reached $65{ }^{\circ} \mathrm{C}$, for 120 days, yielding a cattle manure and hay compost. The vermicompost was obtained by the action of Eisenia andrei BOUCHÉ (1972) earthworms on pure cattle manure for 45 days, without previously going through any composting. According to the manufacturer (Esa Soluções Ambientais, Brazil), the commercial substrate Tecnomax ${ }^{\mathrm{TM}}$ has a cation exchange capacity (CEC) of $200 \mathrm{cmol}_{\mathrm{c}} \mathrm{dm}^{-3}$, electrical conductivity (EC) of $0.7 \pm 0.3 \mathrm{mS} \mathrm{cm}^{-1}$, and $\mathrm{pH}$ 6.0. Samples of three organic fertilizers and commercial substrate were dried at $65{ }^{\circ} \mathrm{C}$ and ground for analysis. Carbon (C) and Nitrogen $(\mathrm{N})$ contents were determined on a CHNS elemental autoanalyzer (Flash model EA 1112, Thermo Finnigan, Milan, Italy) (Table 1). The $\mathrm{pH}$ and contents of Phosphorus (P), Potassium (K), and $\mathrm{N}$ $\left(\mathrm{N}-\mathrm{NH}_{4}^{+}\right.$and $\left.\mathrm{N}_{-} \mathrm{NO}_{2}{ }^{-}+\mathrm{N}^{-} \mathrm{NO}_{3}{ }^{-}\right)$were determined as in TEDESCO et al. (1995) (Table 1). The efficiency indexes were $0.16,0.11$, and 0.14 for $\mathrm{N}, 0.34,0.57$, and 0.48 for $\mathrm{P}$, and $0.17,0.66$, and 0.69 for $\mathrm{K}$ for organic compost, vermicompost, and cattle manure, respectively, calculated in Eckhardt et al. (2018).

\section{Experimental design and seedling production}

The production of Eucalyptus urograndis (clone of E. urophylla ST Blake x E. grandis W. Hill ex Spreng) seedlings was carried out in a greenhouse. The experiment was a completely randomized $3 \times 5+$ 1 factorial design with 20 replicates. The treatments consisted of the three organic fertilizers (in natura, composted, or vermicomposted manure) mixed, in five different percentages $(20 \%, 40 \%, 60 \%, 80 \%$, and $100 \%, \mathrm{v} / \mathrm{v}$ ), with washed sand. The commercial substrate was included as an additional treatment as a control.

The sand was washed once in water, once in a hydrochloric acid solution $(0.5 \% \mathrm{v} / \mathrm{v})$, followed by three additional washes in distilled water. The experimental units consisted of $50 \mathrm{~cm}^{3}$ plastic tubes ( $3 \mathrm{~cm} \varnothing \times 12 \mathrm{~cm}$ of height) containing a seedling. E. urograndis seeds were superficially sterilized in a sodium hypochlorite solution $(1 \% \mathrm{v} / \mathrm{v})$ and pregerminated in petri dishes on moist germination paper, at $25^{\circ} \mathrm{C}$, in the absence of light, for five days.

Table 1 - Chemical attributes of cattle manure, compost, vermicompost, and a commercial substrate, used in Eucalyptus urograndis seedling production.

\begin{tabular}{|c|c|c|c|c|c|c|c|c|}
\hline Treatments & $\mathrm{pH}$ & Org $\mathrm{C}_{\text {total }}$ & $\mathrm{N}_{\text {total }}$ & $\mathrm{NH}_{4}^{+}$ & $\mathrm{NO}_{2}^{-}+\mathrm{NO}_{3}^{-}$ & $\mathrm{C}: \mathrm{N}$ & $\mathrm{P}_{\text {total }}$ & $\mathrm{K}_{\text {total }}$ \\
\hline & - & \multicolumn{4}{|c|}{ 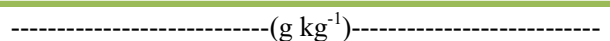 } & - & \multicolumn{2}{|c|}{ 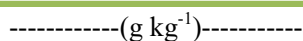 } \\
\hline Cattle manure & 8.1 & 305 & 22.2 & 0.2 & 1.7 & 13.7 & 10.8 & 24.9 \\
\hline Compost & 7.2 & 232 & 19.9 & 0.1 & 1.7 & 11.6 & 19.7 & 20.1 \\
\hline Vermicompost & 8.3 & 228 & 19.7 & 0.1 & 1.8 & 11.5 & 16.5 & 14.5 \\
\hline $\begin{array}{l}\text { Commercial } \\
\text { substrate }\end{array}$ & 5.6 & 361 & 12.8 & 0.06 & 0.3 & 28.2 & 3.8 & 2.3 \\
\hline
\end{tabular}


The germinated seeds were transplanted into the tubes containing the different substrates. After the transplantation, the tubes remained in a greenhouse, with the temperature ranging between 20 and 29 ${ }^{\circ} \mathrm{C}$. Irrigation with distilled water was carried out manually and periodically.

\section{Seedling quality analysis}

One-hundred and twenty days after transplantation, seedling height and stem diameter were determined with a digital calliper. Subsequently, the seedlings were sectioned at the level of the substrate, and the roots were washed in distilled water over a sieve $(\varnothing 0.05 \mathrm{~mm})$. The shoots and roots were dried in a forced air circulation oven set to $65{ }^{\circ} \mathrm{C}$, until reaching a constant mass. The data were used to determine the Dickson quality index (DICKSON et al., 1960):

DQI = Total Dry Mass $/[($ Height $/$ Stem Diameter $)+($ Shoot Dry Matter/Root Dry Matter)].

\section{Statistical analysis}

The data were submitted to a normality test (Shapiro-Wilk with $P<0.05$ ), and to an analysis of variance (ANOVA) and, the comparison between the percentages of the same substrate was performed by regression analysis using SISVAR software (FERREIRA, 2014).

\section{RESULTS}

Composting and vermicomposting modified the chemical attributes of cattle manure (Table 1). The composting process reduced the $\mathrm{pH}$ $(12 \%)$ and $\mathrm{C}: \mathrm{N}$ ratio $(15 \%)$, as well as the content of organic $\mathrm{C}(24 \%)$, total $\mathrm{N}(10 \%), \mathrm{NH}_{4}(50 \%)$, and potassium (19\%), while increasing $\mathrm{P}$-content (82\%). Vermicomposting treatment reduced the content of organic $\mathrm{C}(25 \%)$, total $\mathrm{N}(11 \%), \mathrm{NH}_{4}(50 \%)$, potassium $(41 \%)$, and the $\mathrm{C}: \mathrm{N}$ ratio $(16 \%)$, while the $\mathrm{pH}(3 \%), \mathrm{NO}_{3}(6 \%)$ and $\mathrm{P}(53 \%)$ content increased. Compared to the commercial substrate, the organic fertilizers had higher concentrations of nutrients, particularly $\mathrm{N}$ total (73\% cattle manure, $55 \%$ compost and 53\% vermicompost), mineral $\mathrm{N}(350 \%$ cattle manure, $267 \%$ compost and $283 \%$ vermicompost), total $\mathrm{P}(184 \%$ cattle manure, $418 \%$ compost and $334 \%$ vermicompost), and total $\mathrm{K}(982 \%$ cattle manure, $773 \%$ compost and $530 \%$ vermicompost) content, as well as higher $\mathrm{pH}$ values (45\% cattle manure, $29 \%$ compost and $48 \%$ vermicompost). The three organic fertilizers exhibited features that concur with the prevailing legislation in Brazil for analysed attributes
(BRASIL, 2009) and can be used in the production of forestry seedlings.

Organic fertilizers and their mixture with sand significantly influenced the shoot and root dry masses, seedling height, stem diameters, shoot/root ratio, and Dickson's quality index (Figure 1). The cattle manure yielded a greater shoot and root mass production in Eucalyptus seedlings compared to the other treatments, in all percentages except $100 \%$ (pure manure), where the plants did not survive (Figures 1A and $1 \mathrm{~B})$. Considering the average dry mass of each mixture, manure increased shoot biomass by $13 \%$ (without significant correlation to the percentage), and root biomass by $18 \%$ (dependent on the percentage, $P$ $<0.05$ ), compared to the other treatments.

The organic compost and the vermicompost, mixed with sand $\geq 40 \%$, yielded shoot dry masses very similar to those obtained with the commercial substrate (Figure 1A). Root dry masses showed a positive linear response to the organic compost and vermicompost percentages in the substrate mixture: a $40 \%$ mixture yielded similar results to the commercial substrate; higher percentages increased this mass (Figure 1B). Due to the performance of the three organic fertilizers in root production, the shoot/root ratio decreased as the manure percentage in the substrate increased (except for the $100 \%$ organic compost), which indicates seedlings with well-developed root systems. Cattle manure stood out for having the smallest shoot/root ratios in Eucalyptus seedlings (Figure 1C).

Seedling height was similar between the three organic fertilizers, and very close to the commercial substrate in percentages above $\geq 40 \%$ (Figure 1D). The stem diameter was the only parameter where the commercial substrate performance exceeded the organic fertilizers. Nevertheless, it was surpassed by cattle manure in percentages above $20 \%$ (Figure 1E). The organic compost was like the commercial substrate at $40 \%$ and $60 \%$, whereas the vermicompost was similar only at $60 \%$. The Dickson quality index establishes the relationship between all the analysed parameters (Figure 1F). It indicated that the quality of seedlings produced with all percentages of cattle manure (except $100 \%$ ), was superior to the other treatments. The quality of seedlings produced using organic compost or vermicompost was very similar to seedlings cultivated using the commercial substrate in percentages above $\geq 40 \%$, indicating that they constitute an alternative with technical and environmental feasibility for the production of Eucalyptus seedlings. 


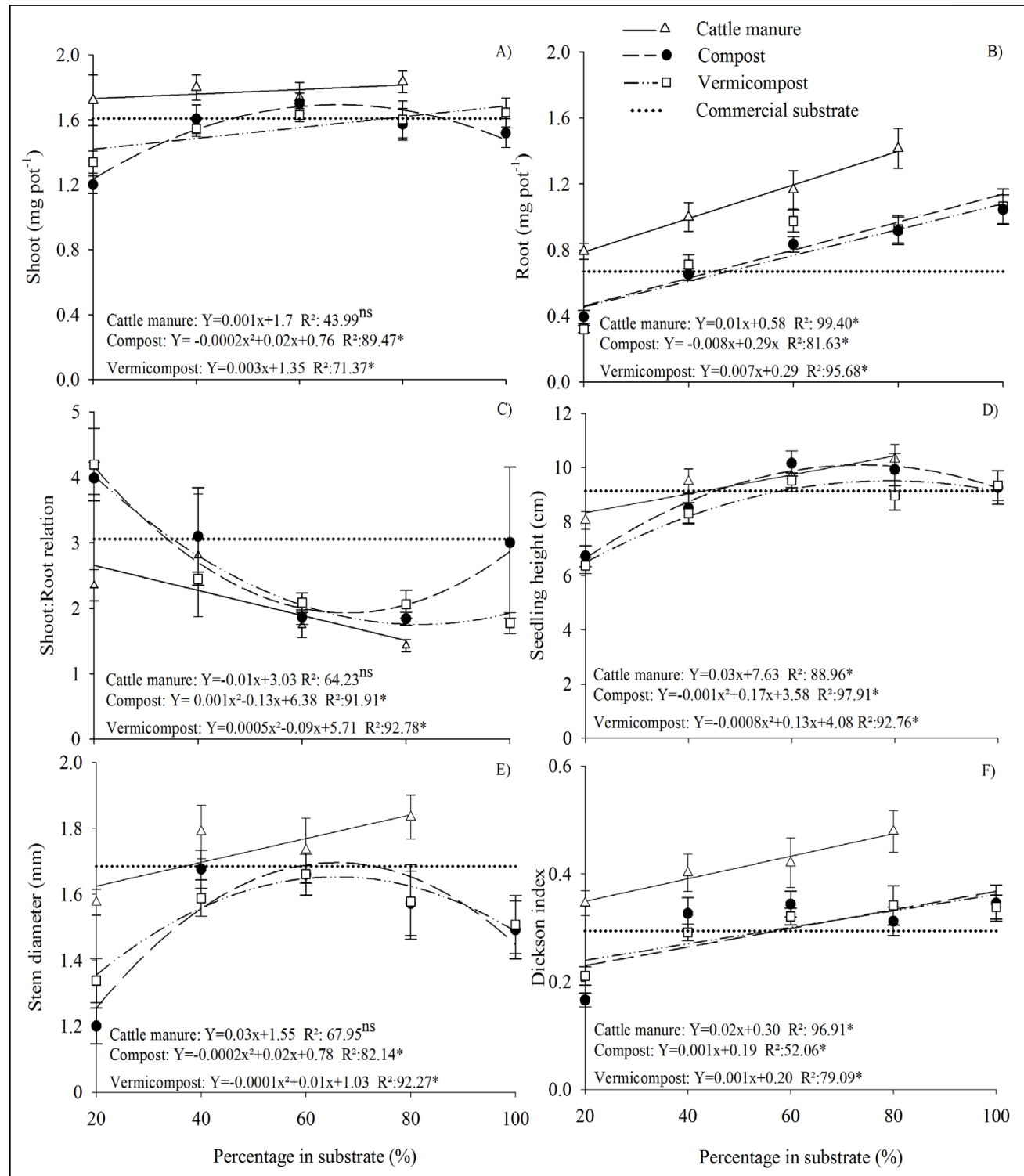

Figure 1 - Shoot (A) and root (B) dry masses, shoot:root ratio (C), seedling height (D), stem diameter (E), and Dickson quality index (F) of Eucalyptus urograndis seedlings after 120 days of cultivation on substrates formulated with cattle manure, organic compost, and vermicompost, in different ratios with washed sand, compared to the commercial substrate (horizontal dotted line). ${ }^{*}$ indicates a significant difference and ns indicates a non-significant difference $(P>0.05)$.

\section{DISCUSSION}

The differences in chemical composition between the three organic fertilizers stem from the composting and vermicomposting processes (mixture of plant residues in the compost, earthworm activity in the vermicompost, and microbial activity in both), since all three are derive from the same cattle manure source. During these processes, a significant fraction of the organic carbon is converted into $\mathrm{CO}_{2}$, resulting in the reduction of organic carbon, the $\mathrm{C}: \mathrm{N}$ ratio, and residue mass, which increased the phosphorus concentration in these fertilizers (GONG et al., 2019). The potassium content decreased because of immobilization in earthworm and microorganism biomasses and/or leaching due to its low capacity to bind to organic matter (DOMÍNGUEZ et al., 2010). The nitrifying bacteria present in the composting and vermicomposting processes oxidized $\mathrm{NH}_{4}^{+}$to $\mathrm{NO}_{2}^{-}+$ $\mathrm{NO}_{3}^{-}$, which may have been fixed in the earthworm and 
microorganism biomasses, or lost by denitrification (HAIT et al., 2012). Other modifications not evaluated in this study also occur during the composting and vermicomposting processes. Recently, SANTANA et al. (2020) evaluated 35 characteristics of the grape marc (skins, stalks and seeds) over 2 years of vermicomposting. The $\mathrm{pH}$ and electrical conductivity as well as the dissolved organic $\mathrm{N}$ and $\mathrm{Cu}$ contents decreased, while the $\mathrm{Ca}, \mathrm{S}$, zinc, and $\mathrm{Mn}$ contents increased. Microbial respiration, carboxylesterase, peroxidase, and catalase activities were highest during the first 30 days. In contrast, urease, acid phosphatase, alkaline phosphatase, and arylsulfatase activities were greater after 30 days of vermicomposting.

The E. urograndis seedlings cultivated in substrates containing $20-80 \%$ cattle manure presented the largest shoot and root dry masses, the smallest shoot/root ratios, most of the largest stem diameters, and the highest Dickson quality indices when compared to the other treatments, indicating an excellent performance as a substrate for the development of $E$. urograndis seedlings. This indication considers the quality of the seedling produced exclusively, excluding the risk of contamination to workers, and the environment from handling untreated cattle manure, as will be discussed below. The differences in the chemical composition of the three organic fertilizers and the commercial substrate justify, at least in part, the results of seedling growth. The total nitrogen, ammonium, and potassium contents were higher in manure, in addition to the high levels of total carbon, nitrate + nitrite and phosphorus contents, which may have resulted in better seedling nutrition compared to other treatments. Moreover, the mixture with sand may have provided good physical conditions for root development (REIS et al., 2014). Eucalyptus seedlings cultivated on a substrate of $100 \%$ bovine manure did not survive. The high ammonium content in bovine manure has a phytotoxic effect on plants, limiting their development, or inhibiting seed germination (VARNERO et al., 2007). Moreover, the environmental conditions under which the study was developed render in natura manure unstable and may lead to the release of phytotoxic organic compounds in the decomposition process (OLIVEIRA et al., 2014).

The commercial substrate Tecnomax ${ }^{\mathrm{TM}}$ was chosen for this research because it has been used in many studies where its efficiency in the seedlings production has been proven (KASPARY et al., 2014; BRUM et al., 2016; AFONSO et al., 2017; SILVA et al., 2017b). The lower growth and quality of seedlings cultivated using the commercial substrate compared to cattle manure may also be due to its low
$\mathrm{pH}$, and low levels of macronutrients in comparison. The low $\mathrm{pH}$ reduces the plant's efficiency in using nutrients such as phosphorus, providing less biomass in the initial growth of Eucalyptus (MAEDA \& BOGNOLA, 2012). The availability of nutrients, mainly $\mathrm{N}, \mathrm{P}$ and $\mathrm{K}$, greatly influences the quality of forestry seedlings (TUCCI et al., 2009). Lower availability, as in the case of the commercial substrate, tends to limit seedling development.

The organic compost and the vermicompost exhibited similar chemical features, thus yielding similar seedling growth rates when cultivated in substrates formulated from these fertilizers. Generally, when used in a $20 \%$ amount in the substrate, their performance was worse than the commercial substrate's. It was expected that when used in pure form $(100 \%)$, they would cause greater nutritional imbalances to plants, due to the high $\mathrm{pH}$ and high concentration of nutrients. However, the robustness of the Eucalyptus allowed the seedlings to develop almost normally, except for the smaller stem diameter compared to the commercial substrate. In any case, the literature is quite clear in not recommending the use of pure organic composts and vermicompost for plant cultivation. However, these materials produced seedlings with similar or superior quality to the commercial substrate when mixed with sand in ratios between $40 \%$ and $80 \%$.

High root growth occurred when cultivation was carried out with organic fertilizers, which is a very important characteristic in seedling production (LIMA FILHO et al., 2019). It is likely that the higher $\mathrm{P}$ content contributed to this, compared to the low levels offered by the commercial substrate. Phosphorus supply stimulates root growth in Eucalyptus (ZHOU et al., 2017; VIEIRA et al., 2017). A low shoot/root ratio is beneficial for seedling development, particularly in conditions of low soil fertility, as it results in a higher proportion of the soil being explored by the root system, facilitating greater absorption of nutrients to meet the plant's needs (STEFFEN et al., 2011).

Dickson's quality index is considered a good indicator of seedling quality (SOUZA et al., 2018). According to GOMES (2002), values above 0.2 are considered adequate for the survival (in the field) of Pseudotsuga menziessi and Picea abies seedlings. However, there is no consensus for ideal Dickson index values in Eucalyptus seedlings, which makes it a variable parameter depending on the species, management, substrate, container, and age of the seedlings (ELOY et al., 2013). O Dickson's quality indices calculated in the present study 
ranged from $0.3-0.5$ higher than those determined by STEFFEN et al. (2011), with values lower than 0.21 in substrates based on vermicompost and peat. KRATZ et al. (2013) observed even lower values than previously reported (0.06) using substrates based on rice husks, vermiculite, pine husks, and coconut fibre. ELOY et al. (2013) observed values of 0.49 after 125 days of E. grandis seedling production in tubes with high density of plants per tray, using a commercial substrate.

Untreated cattle manure proved to be an excellent substrate for the growth of Eucalyptus seedlings, mixed with sand at percentages $\leq 80 \%$, probably due to its high concentration of nutrients. However, no analyses were carried out to detect the presence of total and faecal coliforms, pathogenic bacteria, fungi, or worms in this fertilizer. The literature indicates that cattle manure in natura can be a source of pathogenic microorganisms (Aspergillus fumigatus, Petriellidium boydii, Salmonella spp., Escherichia coli, Listeria monocytogenes, inter alia), viruses (Enterovirus, Rotavirus, Parvovirus, among others), and worms (Ascaris lumbricoides, Ancylostoma sp., inter alia), that can be transmitted to those handling this waste (VENGLOVSKY et al., 2006). Furthermore, when untreated, poorly stored cattle manure is a source of environmental contamination with the production of leachate and a bad smell, which attracts insects and rodents. Thus, despite the possibility of producing Eucalyptus seedlings from cattle manure in natura, this practice must be carried out according to technical guidelines to avoid risks to the health of workers and the environment.

The production of Eucalyptus seedlings on substrates produced from a mixture containing $40 \%, 60 \%$, or $80 \%$ vermicompost or organic compost in the mixture with sand proved to be technically viable. Most of the growth parameters of these seedlings were equal to or superior to the commercial substrate. Unlike cattle manure, organic compost and vermicompost present an extremely low load of pathogenic agents (DOMÍNGUEZ et al., 2010; WANG et al., 2018). Moreover, composting and vermicomposting involves mixing of cattle manure with other residues, converting an environmental problem into a high quality, organic fertilizer. The use of organic compost and vermicompost in the formulation of substrates to produce Eucalyptus seedlings facilitates a combination of technical feasibility, health security, and environmental and economic sustainability.

\section{CONCLUSION}

The substrate formulated from a mixture of $80 \%(\mathrm{v} / \mathrm{v})$ of cattle manure in natura and washed sand allows for better development in Eucalyptus seedlings. Substrate containing $100 \%$ bovine manure vermicompost or organic compost produced seedlings of lower quality compared to cattle manure in natura, though they were superior to seedlings given the commercial substrate. Due to the health risks associated with use of untreated bovine manure, compost and vermicompost are a good alternative for the production of E. urograndis seedlings.

\section{ACKNOWLEDGMENTS}

The authors thank the Conselho Nacional de Desenvolvimento Científico e Tecnológico - Brasil (CNPq) and Coordenação de Aperfeiçoamento de Pessoal de Nível Superior - Brasil (CAPES) - Finance Code 001, for the scholarships and funding support.

\section{DECLARTION OF CONFLICT OF INTEREST}

The authors declare no conflict of interest. The founding sponsors had no role in the design of the study; in the collection, analyses, or interpretation of data; in the writing of the manuscript, and in the decision to publish the results.

\section{AUTHORS' CONTRIBUTIONS}

All authors contributed equally for the conception and writing of the manuscript. All authors critically revised the manuscript and approved of the final.

\section{REFERENCES}

ABREU, A. H. et al. Characterization of biosolids and potential use in the production of seedlings of Schinus terebinthifolia Raddi. Engenharia Sanitária e Ambiental, v.24, n.3, p.591-599, 2019. Available from: <https:/www.scielo.br/pdf/esa/v24n3/1809-4457esa-s1413-41522019108265.pdf >. Accessed: Aug. 08, 2019. doi: $10.1590 /$ S1413-41522019108265.

AFONSO, M. V. et al. Physiological parameters of Albizia niopoides seedlings produced in different substrate compositions. Ciência Florestal, v.27, n.4, p.1395-1402, 2017. Available from: <https://www.scielo.br/scielo.php?script=sci_arttext\&pid $=$ S1980-50982017000401395 $>$. Accessed: Nov. 09, 2020. doi: $10.5902 / 1980509830221$.

BRASIL. Ministério da agricultura, pecuária e abastecimento. Instrução Normativa $\mathbf{n}^{\circ} \mathbf{2 5}$, de 23 de julho de 2009. Aprovar as normas sobre as especificações e as garantias, as tolerâncias, o registro, a embalagem e a rotulagem dos fertilizantes orgânicos simples, mistos, compostos, organominerais e biofertilizantes destinados à agricultura. Available from: <http://sistemasweb.agricultura.gov.br/ sislegis/action/detalhaAto.do?method=recuperarTextoAtoTematicaPo rtal\&codigoTematica=1229186>. Accessed: Jun. 10, 2020. 
BRUM B. et al. Optimum plot size for evaluating the mass and diameter of broccoli heads. Ciência Rural, v.6, n.3, p.447-463, 2016. Available from: <https://www.scielo.br/scielo.php?pid=S0103$84782015005036103 \&$ script $=$ sci_arttext \&tlng $=\mathrm{pt}>$. Accessed: Jun. 20, 2020. doi: 10.1590/0103-8478cr20150236.

DICKSON, A. et al. Quality appraisal of white spruce and white pine seedling stock in nurseries. Forest Chronicle, v.36, n.1, p.1013, 1960. Available from: <https://doi.org/10.5558/tfc36010-1>. Accessed: Feb. 17, 2020. doi: 10.5558/tfc36010-1.

DOMÍNGUEZ, J. M. et al. Influence of vermicompost on plant growth. Contributions toward the development of an objective concept. Acta Zoologica Mexicana, v.26, n.2, p.359-371, 2010. Available from: <http://www.scielo.org.mx/pdf/azm/v26nspe2/ v26nspe2a27.pdf $>$. Accessed: Mar. 25, 2020.

DOMÍNGUEZ, J.; EDWARDS, C. A. Relationships between composting and vermicomposting: relative values of the products. In: EDWARDS, C. A. et al. Vermiculture technology: earthworms, organic waste and environmental management. Boca Raton: CRC Press, 2011. Cap. 2, p. 1-14.

ECKHARDT, D. P. et al. Cattle manure bioconversion effect on the availability of nitrogen, phosphorus, and potassium in soil. Revista Brasileira de Ciência do Solo, v.42, e0170327, 2018. Available from: $\quad<$ http://dx.doi.org/10.1590/18069657rbcs20170327>. Accessed: Aug. 16, 2019. doi: 10.1590/18069657rbcs20170327.

ELOY, E. et al. Quality assessment of Eucalyptus grandis seedlings using morphological parameters. Revista Floresta, v.43, n.3, p.373-384, 2013. Available from: <http://dx.doi.org/10.5380/ rf.v43i3.26809>. Accessed: Nov. 09, 2019. doi: 10.5380 rf.v43i3.26809.

FERMINO, M. H. et al. Reutilization of residues as components of substrate for the production of Eucalyptus grandis seedlings. Cerne, v.24, n.2, p.80-89, 2018. Available from: <https://www. scielo.br/pdf/cerne/v24n2/2317-6342-cerne-24-02-80.pdf>. Accessed: Feb. 01, 2020. doi: 10.1590/01047760201824022522.

FERREIRA, D. F. Sisvar: a Guide for its Bootstrap procedures in multiple comparisons. Ciência e Agrotecnologia, v.38, n.2, p.109-112, 2014. Available from: $<$ https://doi.org/10.1590/S141370542014000200001>. Accessed: Jun. 06, 2020. doi: 10.1590/ S1413-70542014000200001.

GOMES, J. M. et al. Morphological parameters quality for the evaluation of Eucalyptus grandis seedling. Revista Árvore, v.26, n.6, p.655-664, 2002. Available from: <https://doi.org/10.1590/ S0100-67622002000600002>. Accessed: Apr. 04, 2020. doi: $10.1590 / \mathrm{S} 0100-67622002000600002$

GONG, X. Q. et al. Spent mushroom substrate and cattle manure amendments enhance the transformation of garden waste into vermicomposts using the earthworm Eisenia fetida. Journal Environmental Management, v.248, 109263, 2019. Available from: $\quad<$ https://doi.org/10.1016/j.jenvman.2019.109263>. Accessed: May, 07, 2020. doi: 10.1016/j.jenvman.2019.109263.

HAIT, S.; TARE, V. Transformation and availability of nutrients and heavy metals during integrated composting-vermicomposting of sewage sludges. Ecotoxicology and Environmental Safety, v.79, n.1, p.214-224, 2012. Available from: <https://doi. org/10.1016/j.ecoenv.2012.01.004>. Accessed: Feb. 02, 2020. doi: 10.1016/j.ecoenv.2012.01.004
KASPARY, T. E. et al. Photosynthetic pigments in Italian ryegrass susceptible and resistant to the herbicide glyphosate. Ciencia Rural, v.44, n.11, p.1901-1907, 2014. Available from: $<$ http://www.scielo.br/scielo.php?script=sci arttext\&pid=S010384782014001101901\&lng=pt\&nrm=iso>. Accessed: Nov. 06, 2020. doi: 10.1590/0103-8478cr20131177.

KRATZ, D. et al. Renewable substrates in the seedling production of Eucalyptus benthamii. Ciência Florestal, v.23, n.4, p.607-621, 2013. Available from: <http://dx.doi. org/10.5902/1980509812345>. Accessed: Jan. 22, 2020. doi: $10.5902 / 1980509812345$.

LIMA FILHO, P. et al. Seedling production of Ceiba speciosa in different volume of tubes using biosolids as substrate. Ciência Florestal, v.29, n.1, p.27-39, 2019. Available from: $<$ https://doi. org/10.5902/1980509819340>. Accessed: Dec. 21, 2019. doi: https://doi.org/10.5902/1980509819340.

LISBOA, A. C. et al. Growth and seedlings quality of Handroanthus heptaphylluswith cattle manure in the substrate composition. Pesquisa Florestal Brasileira, v.38, n.1-6. e201701485, 2018. Available from: <https://pfb.cnpf.embrapa.br/pfb/index.php/pfb/ article/view/1485>. Accessed: Jun. 10, 2020. doi: 10.4336/2018. pfb.e201701485.

MAEDA, S.; BOGNOLA, I. A. Influence of lime and phosphorus in initial growth of eucalyptus and in $\mathrm{P}$ critical level. Pesquisa Florestal Brasileira, v.32, n.72, p.401-407, 2012. Available from: $<$ https://doi.org/10.4336/2012.pfb.32.72.401>. Accessed: Jan. 15, 2020. doi: $10.4336 / 2012$.pfb.32.72.401.

MANÁKOVÁ, B. et al. Effects of combined composting and vermicomposting of waste sludge on arsenic fate and bioavailability. Journal of Hazardous Materials, v. 280, p. 544-551, 2014. Available from: $<$ https://doi.org/10.1016/j.jhazmat.2014.08.024>. Accessed: Apr. 10, 2020. doi: 10.1016/j.jhazmat.2014.08.024.

OLIVEIRA, L. C. et al. Cattle manure and coconut fiber for baruzeiro seedling. Revista de Agricultura Neotropical, v.1, n.2, p.42-51, 2014. Available from: <https://periodicosonline.uems. br/index.php/agrineo/article/view/240>. Accessed: Apr. 08, 2020. doi: 10.32404/rean.vli2.240.

REIS, J. M. R. et al. Production of seedlings of yellow passion fruit in different compositions of substrate and environment. Enciclopédia Biosfera, v.10, n.18, p.2423-2428, 2014. Available from: <https://revistas.unoeste.br/index.php/ca/article/ view/2299>. Accessed: Feb. 15, 2020.

SANTANA, N. A. et al. Changes in the chemical and biological characteristics of grape marc vermicompost during a two-year production period. Applied Soil Ecology, v.154, p.1-9, 2020. Available from: <https://www.sciencedirect.com/science/article/ abs/pii/S0929139319311953?via\%3Dihub>. Accessed: Nov, 14, 2020. doi: 10.1016/j.apsoil.2020.103587.

SILVA, R, F. et al. Influence of Different Concentrations of Vermicompost in the Development of Eucalyptus and Pine Seedlings. Floresta e Ambiente, v.24, e20160269, 2017a. Available from: <http://dx.doi.org/10.1590/2179-8087.026916.>. Accessed: May, 14, 2020. doi: 10.1590/2179-8087.026916.

SILVA, R. F et al. R. Proportion of vermicompost and vermiculite in the production of seedlings of angico vermelho and timbaúva. Revista Holos, v.8, p.32-41, 2017b. Available from: <http:// 
www2.ifrn.edu.br/ojs/index.php/HOLOS/article/view/4607/pdf>. Accessed: Nov. 02, 2020. doi: 10.15628/holos.2017.4607.

SOUZA, J. A. R. et al. Eucalyptus seedlings development submitted to fertirrigation with swine wastewater. Revista Ibero-Americana de Ciências Ambientais, v.9, n.7, p.280-288, 2018. Available from: <https://doi.org/10.6008/CBPC21796858.2018.007.0026>. Accessed: Jan. 21, 2020. doi: 10.6008/ CBPC2179-6858.2018.007.0026.

STEFFEN, G. P. K. et al. Use of vermicompost as a substrate for the production of Eucalyptus grandis and Corymbia citriodora seedlings. Pesquisa Florestal Brasileira, v.31, n.66, p.75-82, 2011. Available from: <https://pdfs.semanticscholar.org/adbd/ ce74b7643d61e6d096536e1af46e252df371.pdf>. Accessed: Sep. 20, 2019. doi: 10.4336/2011.pfb.31.66.75.

TEDESCO, M. J. et al. Análise de solo, plantas e outros materiais. Porto Alegre, Universidade Federal do Rio Grande do Sul. 1995. 174p.

TUCCI, C. A. F. et al. Nitrogen fertilization in the production of seedlings of mahogany (Swietenia macrophylla King). Acta Amazonica, v.39, n.2, p.289-294, 2009. Available from: <https:// doi.org/10.1590/S0044-59672009000200007>. Accessed: Dec. 17, 2020. doi: 10.1590/S0044-59672009000200007.

VARNERO, M. T. M. et al. Phytotoxicity indices of organic residues during composting. Journal of Soil Science and Plant
Nutrition, v.7, n.1, p.28-37, 2007. Available from: <http://dx.doi. org/10.4067/S0718-27912007000100003>. Accessed: Apr. 06, 2020. doi: $10.4067 / \mathrm{S} 0718-27912007000100003$.

VENGLOVSKY, J. et al. Hygienic and ecological risks connected with utilization of animal manures and biosolids in agriculture. Livestock Science, v.102, n.3, p.197-203, 2006. Available from: $<$ https://doi.org/10.1016/j.livsci.2006.03.017>. Accessed: Apr. 04, 2020. doi: 10.1016/j.livsci.2006.03.017.

VIEIRA, C. R.; WEBBER, O. L. S. Mineral fertilization and limestone on the growth of Eucalyptus camaldulensis seedlings. Ecologia e Nutrição Florestal, v.5, n.2, p.45-52, 2017. Available from: <https://doi.org/10.5902/2316980X27343>. Accessed: Aug. 17, 2019. doi: $10.5902 / 2316980 \times 27343$.

WANG, K. et al. Changes in structure and function of fungal community in cow manure composting. Bioresource Technology, v.255, p.123-130, 2018. Available from: <https://doi.org/10.1016/j. biortech.2018.01.064>. Accessed: Aug. 06, 2019. doi: 10.1016/j. biortech.2018.01.064.

ZHOU, C. et al. Morphological plasticity and phosphorus uptake mechanisms of hybrid Eucalyptus roots under spatially heterogeneous phosphorus stress. Journal of Forestry Research, v.28, n.4, p.713-724, 2017. Available from: <https://doi. org/10.1007/s11676-016-0335-x>. Accessed: Aug. 24, 2019. doi: $10.1007 / \mathrm{s} 11676-016-0335-\mathrm{x}$ 